\title{
Seed germination characteristics and control options for Noogoora bur (Xanthium strumarium) in commercial maize production
}

\author{
T.K. James, A. Rahman, M.R. Trolove and C.A. Dowsett \\ AgResearch, Ruakura Research Centre, Private Bag 3123, Hamilton 3240, New Zealand \\ Correspondingauthor: trevor.james@agresearch.co.nz
}

\begin{abstract}
Noogoora bur (Xanthium strumarium) is a large, herbaceous, highly competitive annual weed of arable and horticultural crops which is subject to Regional Pest Management Plans in the Waikato and Bay of Plenty regions, New Zealand. A study with scarified burs showed that most plants emerged from $0-40 \mathrm{~mm}$ and none from $100 \mathrm{~mm}$ depth. Plants emerged after 8 days from 0-30 $\mathrm{mm}$, after 14 days from $90 \mathrm{~mm}$ and continued to emerge over summer, with some also germinating in the second year after initiation. Cultivated fallow resulted in germination of similar numbers of seeds over two growing seasons with no new seed input. Results from a field trial showed that dicamba and atrazine, alone or in combination with other products, as well as topramezone, provided good control of this weed in maize crop.
\end{abstract}

Keywords Seed biology, arable crops, maize, weed emergence, weed management

\section{INTRODUCTION}

Noogoora bur (Xanthium strumarium L, also known as common cocklebur) is a large-leaved, tall (up to $2.5 \mathrm{~m}$ high) herbaceous annual weed. Originally from the West Indies and/or Central America, it is now also a weed throughout North and South America, Asia, Africa and Australia. Its name is derived from the bean-sized burs with hooked spines, which grow in profusion in the leaf axils. The leaves are dark green on the upper surface, about $15 \mathrm{~cm}$ in diameter and roughly textured with minute bristles. The stems are woody when mature, coloured green with purple blotching. The flowers are inconspicuous, occurring in the leaf axils toward the ends of branches. The burs adhere readily to livestock and clothing.
Xanthium spp. (including Noogoora bur) are serious weeds of summer and horticultural crops (van Klinken \& Julien 2003). In New Zealand, Noogoora bur is a notifiable pest plant subject to eradication in the Regional Pest Management Plans for both Waikato (Anon. 2016a) and Bay of Plenty (Anon 2016b). There are three known infestations in the Waikato region and 16 in Bay of Plenty. The most serious infestation in Bay of Plenty was contained until the area flooded, which is a well-documented dispersal mechanism for this species (Parsons \& Southwell 2015; Auld \& Medd 1987). Noogoora bur currently covers about 100 ha on just one property at Papamoa in Bay of Plenty. The Bay of Plenty Regional Council has organised and financed the manual removal of 
this weed from Papamoa because, if this weed continues to spread, it will most likely reduce the value of arable and pasture farms nearby.

Noogoora bur has a C3 photosynthetic pathway and conditions for its germination and growth are very similar to two other problematic $\mathrm{C} 3$ weeds of arable crops in New Zealand: thorn apple (Datura stramonium L.) and velvet leaf (Abutilon theophrasti Medik.) (Loddo et al 2013). The seeds of Noogoora bur are larger (9-10 $\mathrm{mm}$ long) and have a softer coat than these two other weeds, but are enclosed in a very tough, spiny bur (15-25 $\mathrm{mm}$ long) that is resistant to abrasion and other germination initiators. Annual survival rate in the soil seed bank is up to 33\% (Martin \& Carnahan 1981). There are two seeds inside each bur; one is generally dormant while the other germinates readily throughout the summer following release by the bur in autumn. The second seed readily germinates in the second year under favourable conditions for seed germination (Martin \& Carnahan 1981; 1983). Staggered germination and carryover of seed from year-to-year make Noogoora Bur a weed pest that is particularly difficult to control.

Effective management of Noogoora bur in arable systems will most likely involve both chemical and cultural methods. One of the traditional cultural methods is to bury the burs with a soil inversion process such as ploughing to a depth below which they cannot emerge (Bararpour 1998). However, this potential control method becomes effective only if the burs are unable to germinate from a depth that is practical to plough. In general, disturbance of the soil by shallow cultivation during summer may also be a practical method of reducing the survival rate of soil seed banks (Martin \& Carnahan 1981).

The objective of the study was to investigate: i) Factors affecting the emergence of seeds from burs; and ii) Options for chemical control in maize cropping systems.

\section{MATERIALS AND METHODS Initial germination test}

Burs were collected from mature plants located at Papamoa in Bay of Plenty during the summer of
2014/15. Half of the burs were scarified by grinding off some of the outer layer of the husk to break physical dormancy and to encourage germination. The viability of these burs was assessed through an initial germination test (ISTA 2015). Four replicates of ten scarified and ten non-scarified burs were placed onto a paper towel, moistened with water, and sealed in plastic zip-locked bags. These bags were stored in a HortiMax ${ }^{\circledR}$ controlled environment room, $16 \mathrm{~h}$ dark at $20 \pm 0.5^{\circ} \mathrm{C}$ and $8 \mathrm{~h}$ light at $30 \pm 0.5^{\circ} \mathrm{C}$. The number of seeds that germinated was counted when radicals emerged. Germination was monitored for 6 weeks.

\section{Germination from different soil depths}

Depth of emergence was investigated using 48 PVC tubes, each $100 \mathrm{~mm}$ in diameter and $50-150 \mathrm{~mm}$ long. These were filled with Horotiu silt loam soil and 10 scarified burs placed on top. Further tubes were added above this and subsequently filled with the same soil so that the total column height was $150 \mathrm{~mm}$ and the burs were buried 0,5 and $10 \mathrm{~mm}$ deep, and then at $10 \mathrm{~mm}$ increments to $100 \mathrm{~mm}$ deep. There were four replicate columns for each depth. The columns were maintained with both top- and sub-irrigation to keep the soil moist. The tubes with buried burs were stored in a HortiMax ${ }^{\circledast}$ controlled glasshouse at a night time min. of $15^{\circ} \mathrm{C}$ and daytime max. of $25^{\circ} \mathrm{C}$. They were checked three times a week for emergence of seedlings for 3 months, after which time no more seedlings emerged. Once the emergence time had been recorded, the newly-emerged plants were severed $10 \mathrm{~mm}$ above the ground so that further emergence of other seeds was not inhibited. The columns were retained in the glasshouse over winter and seedling emergence recorded the following summer.

\section{Germination from cultivated soil}

A small portion of a maize field at the Papamoa site was power harrowed $230 \mathrm{~m}$ long by $4.5 \mathrm{~m}$ wide and $150 \mathrm{~mm}$ deep on 14 November 2013, and again on 4 December 2013. Although the site was generally infested with Noogoora bur, none 
were present prior to the first cultivation of the strip. Further discing was carried out on the same strip of ground at monthly intervals in January and February 2014. In the second maize growing season, the same strip was cultivated again in December 2014, January and February 2015. The number of Noogoora bur seedlings that emerged in the strip was counted approximately 3 weeks after each cultivation, and in mid-April each season. As all Noogoora bur seedlings were removed after each count and other weeds were controlled by the cultivation, this monitoring procedure ensured that no new seed was introduced to the site.

\section{Seed survival in maize silage}

Twenty-four batches, each of 25 scarified or non-scarified burs, were counted into nylon mesh bags. Twenty each of the scarified and non-scarified bur bags were buried in a covered maize silage stack at a depth of $250-400 \mathrm{~mm}$ in central Waikato on 17 April 2015, 6 weeks after the stack was formed. The temperature in the silage stack was recorded at $15 \mathrm{~min}$ intervals using a Tinitag datalogger buried with the nylon bags. Four each of the scarified and non-scarified bur bags in the silage stacks were retrieved 14, 28, 42, 56 and 84 days after burial. The burs from these bags were planted out in seed propagation trays filled with

Table 1 Post-emergence herbicide treatments ${ }^{1}$ evaluated for control of Noogoora bur.

\begin{tabular}{|c|c|c|c|c|}
\hline $\begin{array}{l}\text { Tr. } \\
\text { No }\end{array}$ & $\begin{array}{l}\text { Post-em } 1 \\
(2 \mathrm{WPE})^{2}\end{array}$ & Rate (g ai/ha) & $\begin{array}{l}\text { Post-em } 2 \\
(5 \mathrm{WPE})^{2}\end{array}$ & $\begin{array}{l}\text { Rate } \\
\text { (g ai/ha) }\end{array}$ \\
\hline 1 & Control: no post-em & - & Control: no post-em & - \\
\hline 2 & dicamba $^{3}$ & 300 & - & - \\
\hline 3 & nicosulfuron & 60 & nicosulfuron & 60 \\
\hline 4 & nicosulfuron + dicamba & $60+300$ & - & - \\
\hline 5 & $\begin{array}{l}\text { mesotrione + atrazine + } \\
\text { Synoil }^{\mathrm{TM}}\end{array}$ & $96+500+1 \%$ & $\begin{array}{l}\text { mesotrione }+ \text { atrazine }+ \\
\text { Synoil }^{\mathrm{TM}}\end{array}$ & $\begin{array}{l}96+500 \\
1 \%\end{array}$ \\
\hline 6 & $\begin{array}{l}\text { mesotrione + atrazine }+ \\
\text { dicamba }+ \text { Synoil }^{\mathrm{TM}}\end{array}$ & $\begin{array}{l}96+500+300+ \\
1 \%\end{array}$ & - & - \\
\hline 7 & $\begin{array}{l}\text { topramezone }+ \text { atrazine }+ \\
\text { Hasten }^{\mathrm{TM}}\end{array}$ & $67+500+0.5 \%$ & $\begin{array}{l}\text { topramezone }+ \text { atrazine }+ \\
\text { Hasten }^{\mathrm{TM}}\end{array}$ & $\begin{array}{l}67+500+ \\
0.5 \%\end{array}$ \\
\hline 8 & $\begin{array}{l}\text { topramezone }+ \text { atrazine }+ \\
\text { Hasten }^{\mathrm{TM}}+\text { dicamba }\end{array}$ & $\begin{array}{l}67+500+0.5 \% \\
+300\end{array}$ & - & - \\
\hline 9 & atrazine & 1500 & atrazine + Synoil $^{\mathrm{TM}}$ & $1500+1 \%$ \\
\hline 10 & atrazine + dicamba & $1500+300$ & - & - \\
\hline 11 & nicosulfuron + mesotrione & $60+96$ & $\begin{array}{l}\text { nicosulfuron }+ \\
\text { mesotrione }\end{array}$ & $60+96$ \\
\hline 12 & $\begin{array}{l}\text { nicosulfuron }+ \text { mesotrione } \\
+ \text { dicamba }\end{array}$ & $\begin{array}{l}60+96 \\
+300\end{array}$ & & - \\
\hline
\end{tabular}

${ }^{1}$ All plots, including control plots, were treated pre-emergence with acetochlor (2520 g ai/ha).

${ }^{2} \mathrm{WPE}=$ weeks post-crop emergence.

${ }^{3}$ Herbicide, oil and adjuvant formulations; dicamba (Banvel ${ }^{\circledR}, 200 \mathrm{~g} /$ litre dimethylamine salt, soluble concentrate, Orion Crop Protection), nicosulfuron (Astound Ultra ${ }^{\circledR}, 40$ g/litre, oil dispersion, Orion Crop Protection), mesotrione (Callisto ${ }^{\circledR}, 480 \mathrm{~g} /$ litre, suspension concentrate, Orion Crop Protection), topramezone (Arietta ${ }^{\oplus}, 336 \mathrm{~g} /$ litre, suspension concentrate, BASF New Zealand Ltd), atrazine (Gesaprim ${ }^{\circledast} 500$ FW, 500 g/litre, suspension concentrate, Orion Crop Protection), crop oil concentrate (Synoil $^{\mathrm{TM}}$, a blend of paraffinic oil and polyglycol fatty acid esters, Orion Crop Protection), adjuvant (Hasten $^{\mathrm{TM}}$, a blend of esterified canola oil and non-ionic surfactant, BASF New Zealand Ltd). 
Dalton's seed-raising mix. On the day that 20 bags were buried (Day 0), the burs in the four remaining bags were planted. Seeds from the unburied bags were the control. The propagation trays from the treated and the control were stored in a HortiMax ${ }^{\circledast}$ controlled environment room as described above, and watered as required. Emergence of all seedlings was monitored for 6 weeks post-planting.

\section{Options for chemical control of Noogoora Bur}

A field trial was conducted during the 2013/2014 season at the Papamoa site infested with Noogoora bur to evaluate selective herbicides for its control in maize. The soil type was a sandy loam laid over peat, with $\mathrm{pH}$ of 5.3 and organic carbon of $6.1 \%$. Plots were $3 \mathrm{~m} \mathrm{x} 12 \mathrm{~m}$. Each plot contained four rows of maize and treatments were replicated four times in a randomised block design. Maize was planted on 22 October 2013 and the whole trial area, along with the rest of the field, was treated pre-emergence with acetochlor (Sylon ${ }^{\circledR} 840,840$ g/litre, emulsifiable concentrate, Orion Crop Protection) at $2.5 \mathrm{~kg}$ ai/ha by the farmer. All the post-emergence herbicides were applied by researchers with a precision $\mathrm{CO}_{2}$-pressurised back pack sprayer with a boom fitted with four TeeJet 11003 nozzles at $75 \mathrm{~cm}$ spacing to deliver 200 litres/ha at 170 $\mathrm{kPa}$. The first post-emergence treatments (Post-em

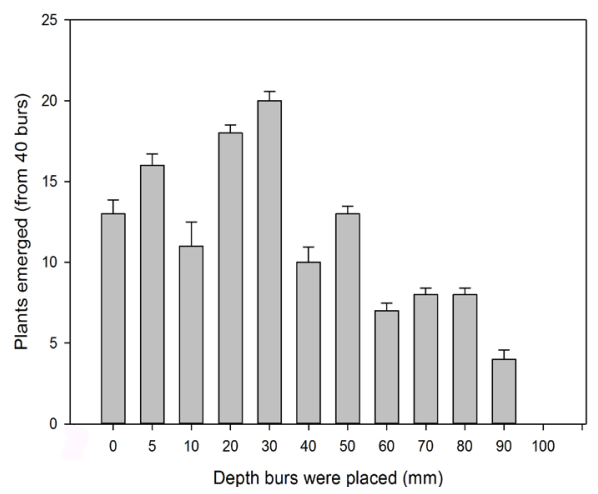

Figure 1 Mean cumulative emergence of Noogoora bur plants over 3 months from 40 scarified burs buried at each depth. Error bars are standard error of the mean (SEM).
1) were applied on 14 November 2013 when the maize plants were about $18 \mathrm{~cm}$ high with about five leaves. The 12 treatments (Table 1) included a no-post-emergence-herbicide control and selective herbicides currently registered in New Zealand to control broadleaf weeds in maize, which were expected to be efficacious against Noogoora bur. The second post-emergence treatments (Post-em 2) were applied on 6 December 2013 to maize at the 12-leaf stage, by repeat application of the same herbicides to the same plots of Treatments 3, 5, 7, 9 and 11. The major difference between these treatments was that herbicide mixtures with dicamba were evaluated to determine if they would provide sufficient residual activity and not require a second post-emergence application. The efficacy of these mixtures was thus compared to repeat applications (Post-em 2) of the herbicide when used alone. The main broadleaf weeds other than Noogoora bur included fathen (Chenopodium album L.), willow weed (Persicaria maculosa Gray), redroot (Amaranthus powellii S.Watson), fishtail oxalis (Oxalis latifolia Kunth) and broad-leaved dock (Rumex obtusifolius L.). The two grass weeds present were summer grass (Digitaria sanguinalis (L.) Scop.) and smooth witchgrass (Panicum dichotomiflorum Michx.). The trial received a starter fertiliser at planting and urea at rates that

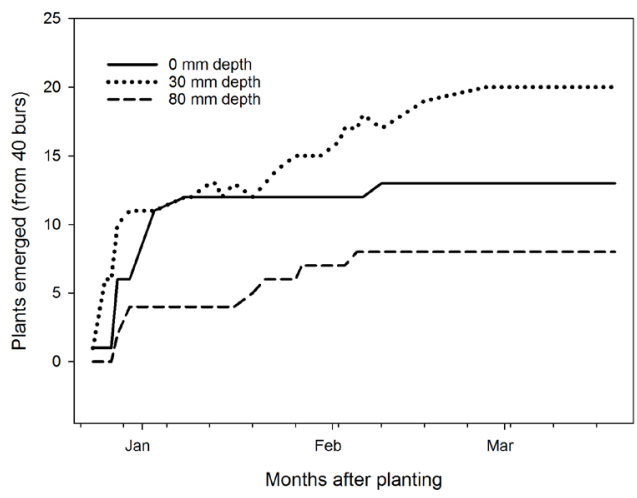

Figure 2 Sequential emergence of Noogoora bur over 3 months from three selected depths: 0,30 and $80 \mathrm{~mm}$. 
Table 2: Total number of Noogoora bur plants (sum of 4 replicates) and weed control scores for various treatments listed in Table 1.

\begin{tabular}{|c|c|c|c|c|c|c|}
\hline \multirow[b]{2}{*}{ Treatment } & \multirow{2}{*}{$\begin{array}{c}\text { Pre-spray } \\
14.11 .2013\end{array}$} & \multicolumn{2}{|c|}{ Post-em 1 (14.11.2013) } & \multicolumn{2}{|c|}{ Post-em $2(06.12 .2013)$} & \multirow{2}{*}{$\begin{array}{c}09.01 .2014 \\
\% \\
\text { Control }^{3} \\
\end{array}$} \\
\hline & & $3 \mathrm{WAT}^{1}$ & $\begin{array}{c}\% \\
\text { Reduction }^{2} \\
\end{array}$ & $5 \mathrm{WAT}^{1}$ & $\begin{array}{c}\% \\
\text { Reduction }^{2} \\
\end{array}$ & \\
\hline 1 & 93 & 101 & - & 120 & - & 0 \\
\hline 2 & 9 & 1 & 89 & 0 & 100 & 50 \\
\hline 3 & 40 & 37 & 9 & 3 & 92 & 96 \\
\hline 4 & 6 & 1 & 83 & 4 & 33 & 75 \\
\hline 5 & 13 & 2 & 85 & 0 & 100 & 99 \\
\hline 6 & 17 & 1 & 94 & 1 & 94 & 86 \\
\hline 7 & 8 & 0 & 100 & 0 & 100 & 99 \\
\hline 8 & 7 & 4 & 43 & 5 & 29 & 85 \\
\hline 9 & 119 & 8 & 93 & 0 & 100 & 48 \\
\hline 10 & 4 & 2 & 50 & 1 & 75 & 64 \\
\hline 11 & 26 & 9 & 65 & 1 & 96 & 99 \\
\hline 12 & 1 & 3 & 0 & 0 & 100 & 86 \\
\hline
\end{tabular}

${ }^{1}$ WAT $=$ weeks after treatment

${ }^{2}$ Percentage reduction from the original pre-spray population

${ }^{3}$ Weed control score $(0=$ no control, $100=$ complete control $)$ for weeds other than Noogoora bur 5 weeks after the Post-em 2 treatment. LSD $(\mathrm{P}<0.05)=10.1$

would normally be applied in commercial practice.

Noogoora bur plants ranged in size from newly emerged to about $300 \mathrm{~mm}$ tall at the time of the post-emergence spray application on 14 November 2013. All the Noogoora bur plants in each plot were counted immediately prior to the herbicide application and three times after treatment to determine the treatment efficacy. Additionally, visual assessments of overall weed control efficacy were also made on 16 December 2013 and 9 January 2014 by assigning scores on a $0-100$ scale taking into account the density, health and vigour of the weeds present in treated plots compared to the control (Treatment 1). The scores were subjected to ANOVA in order to calculate the arithmetic means and the least significant differences (LSD).

\section{RESULTS}

\section{Initial germination test}

After 6 weeks in the controlled environment the initial germination rate of the scarified burs was $40 \%$, while those of the non-scarified burs was only $17.5 \%$.

\section{Germination from different soil depths}

Seedlings emerged after 8 days from burs planted $30 \mathrm{~mm}$ deep or less, and after 14 days from burs planted $90 \mathrm{~mm}$ deep. No plants emerged from burs planted $100 \mathrm{~mm}$ deep. Total emergence from each depth is presented in Figure 1. About half of the seedlings emerged in the first 3 weeks, although emergence continued at a slower rate for the 3 -month duration of the study in the first year (Figure 2).

The same PVC pipes were re-examined a year later (summer 2015/16). Seedlings began to emerge from late October 2015 and continued until late February 2016. Nineteen seedlings emerged in the second season mostly from burs buried less than $60 \mathrm{~mm}$ deep. One single seedling emerged from $90 \mathrm{~mm}$ deep, but there was no emergence from $100 \mathrm{~mm}$.

\section{Germination from cultivated soil}

In the first season a total of 400 seedlings emerged from the cultivated strip: 209 seedlings (16 December 2013), 153 (9 January 2014), 38 (12 
February 2014) and none on 8 April 2014. In the second season, 395 seedlings emerged from the same cultivated strip: 370 (16 December 2014), 9 (12 January 2015) and 16 (10 April 2015). Nearly equal numbers of seedlings were counted in each growing season, suggesting that one of the two seeds in each bur may have germinated each year.

\section{Seed survival in maize silage}

Emergence of seedlings in the controls from scarified and non-scarified burs was $21 \%$ (range $4-28 \%$, SEM 6\%) and 3\% (range 0-8\%, SEM 2\%), respectively. The temperature in the silage stack peaked at $23^{\circ} \mathrm{C}$ approximately 7 days after the burs were buried and gradually declined to a minimum of $12^{\circ} \mathrm{C}$ at the end of the study which was 84 days after the burs were buried. No seedlings emerged from any of the retrieved buried burs.

\section{Options for chemical control of Noogoora Bur}

The number of Noogoora bur plants on 14 November 2013 before post-emergence spraying served as the starting point to determine post-emergence herbicide efficacy (Table 2). The variability in plant numbers reflects the patchiness of the infestation with the first replicate having more weeds than the other three replicates. Plants counted on 4 December 2013, 3 weeks after the application of the first post-emergence treatments (Post-em 1), showed that most of the herbicides, when used alone, provided good control of Noogoora bur (>80\%). Nicosulfuron used alone (Treatment 3) resulted in only 9\% reduction from the pre-spray control, while nicosulfuron used with mesotrione (Treatment 11) resulted in only $65 \%$ reduction (Table 2 ).

All herbicides were evaluated alone as well as in combination with dicamba, which was expected to give some residual control of Noogoora bur. Results show that an improvement in efficacy occurred only in the case of nicosulfuron (Treatment $3 \mathrm{cf}$. Treatment 4 ). In the case of topramezone which was very effective on its own (Treatment 7), there was a possible loss of efficacy when combined with dicamba (Treatment 8). Both dicamba and atrazine provided very good control of Noogoora bur when used alone (Treatments 2 and 9, respectively) as well as in combination with most other herbicides (Table 2).

The second post-emergence treatment (Post-em 2) was applied on 6 December 2013 to plots that did not receive dicamba previously. Counts 5 weeks after treatment show an improvement in the reduction in Noogoora bur plants from the original population (Table 2). The repeat application of the same herbicide (Treatments $3,5,7,9$ and 11) provided good control (>90\% reduction) of Noogoora bur plants in these plots.

Overall control scores for all weeds 10 and 34 days after the second application (Post-em 2) were low for dicamba, atrazine and their combination (Treatments 2, 9 and 10) due to their low efficacy on grasses, and fathen in the case of atrazine. Those with lower efficacy (scores of 75-86\%) were Treatments 4, 6, 8 and 12, all of which did not receive the repeat application on 6 December 2013, but did include dicamba (Table 2). These plots had only seedling summer grass plus oxalis in some cases, which were unlikely to have a significant effect on crop growth or yield. Those with excellent efficacy (scores of 93-99) included Treatments 3, 5,7 and 11, which received the second application (Post-em 2). The only exception was atrazine (Treatment 9) where the repeat application neither controlled fathen nor the grass weeds.

\section{DISCUSSION}

Results from this field trial suggest that atrazine plus dicamba could be an option for control of Noogoora bur if there are few grass weeds present, otherwise a treatment with topramezone is best as it will also control grass weeds. Atrazine and dicamba have an average residual half-life of 29 and 20 days respectively. Even though atrazine has slightly more residual activity, in New Zealand it is usually applied pre-emergence and its usefulness is sometimes limited due to herbicide resistance and lack of efficacy on difficult-to-control weeds. Therefore, dicamba is frequently applied 
post-emergence to control difficult weeds and this herbicide usually provides some residual control.

This study showed that Noogoora bur was able to germinate over a lengthy time period (two seasons) despite being scarified. As the seed can readily emerge from up to $90 \mathrm{~mm}$ depth, ploughing at depths of less than $150 \mathrm{~mm}$ would probably not be an effective control measure. Martin \& Carnahan (1983) observed innate dormancy in one of the two seeds in each bur but this could be overcome by high temperature and exposure to light. However, induced dormancy was observed in the other seed following storage in soil over summer and this was overcome by storage in soil over winter. Results of the field trial confirm the observations of continued emergence over summer months in the seedling emergence experiment, which highlights the main difficulty in controlling this weed. The continual seedling emergence leaves few options apart from repeat post-emergence herbicide applications over several years.

None of the 400 scarified seeds buried in the silage stack germinated (compared to $21 \%$ of the 100 scarified control seeds), which indicates that there are as yet unknown processes within the silage stack that have the ability to denature Noogoora bur seed.

The combination of a long seedling emergence period, as well as the presence of dormant seeds over more than a year, makes complete management of Noogoora bur by herbicides alone difficult in maize crops. Optimal control may require discing to promote early germination, repeated pre- and post-mergence herbicide applications and hand-rogueing over several growing seasons. Other management options, such as summer fallow or shifting to pastoral farming, could also be worth considering although the latter may only force the Noogoora bur seed into longer dormancy. When managing an incursion species such as Noogoora bur, the control of other weeds is also very important. If weeds are present in the commercial crop the manual scouting for Noogoora bur plants becomes even more difficult. Noogoora bur seedlings emerged in greater numbers in the small furrow caused by the knifing of urea into the soil, which raises another issue for better managing this weed pest.

\section{ACKNOWLEDGEMENTS}

Thanks are due to Daniel Dovaston of Papamoa for providing the trial site and helping with various field activities; to Mike Parker of the Foundation of Arable Research and to Andrew Blayney and Shane Grayling, Land Management Officers of the Bay of Plenty Regional council, for help with the field trial. Financial support for this project was provided by the Foundation for Arable Research, Bay of Plenty Regional Council and the Waikato Regional Council.

\section{REFERENCES}

Anonymous 2016a. Waikato Regional Pest Management Plan. Control of Noogoora bur. http://www.waikatoregion.govt. nz/PageFiles/7035/Waikato Regional Pest Management Plan_ $2015 \quad 16$ Operational Plan.pdf /

Anonymous 2016b. Sustainable options: Pest plant control. Bay of Plenty Pest Management Plan. https://www.boprc.govt. nz/media/415023/pp33-noogoora-bur-web. pdf

Auld BA, Medd RW 1987. Weeds: An illustrated botanical guide to the weeds of Australia. Inkata Press, Melbourne, Australia. 255 pp. ISBN 0909605378.

Bararpour MT, Oliver LR 1998. Effect of tillage and interference on common cocklebur (Xanthium strumarium) and sicklepod (Senna obtusifolia) population, seed production, and seedbank. Weed science 46:424-431.

ISTA 2015. International Rules for Seed Testing. ISTA Secretariat, CH-8303 Basserdorf Switzerland.

Martin RJ, Carnahan JA 1981. Seed population dynamics, germination and dormancy in Xanthium. Proceedings of the $6^{\text {th }}$ Australian Weeds Conference 1: 21-24.

Loddo D, Sousa E, Masin R, Calha I, Zanin G, Fernández-Quintanilla C, Dorado J 2013. Estimation and base temperature for germination or European populations of velvetleaf (Abutilon theophrasti) and jimson 
weed (Datura stramonium). Weed Science 61: 443-451.

Martin RJ, Carnahan JA 1983. The effect of field storage and laboratory conditions on germination of 5 Xanthium species. Australian Journal of Agricultural Research 34: 249-260.

Parsons M, Southwell M 2015. Flooding and geomorphology influence the persistence of the invasive annual herb Noogoora burr (Xanthium occidentale Bertol.) in the riparian zone of the dryland Darling River, Australia. Rangeland Journal 37: 433-444. van Klinken RD, Julien MH 2003. Learning from past attempts: does classical biological control of Noogoora burr (Asteraceae: Xanthium occidentale) have a promising future? Biocontrol Science and Technology 13: 139-153. 